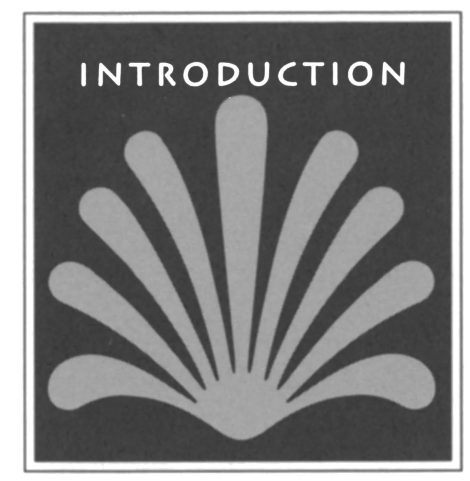

\title{
NICIAS, LAMACHUS,
}

AND ALCIBIADES

Political Allegory in

\section{Aristophanes}

Aristophanes wrote in dangerous times. Attacks on contemporaries had to be carried out with considerable discretion. This was especially advisable since "the kind of person who [was] usually lampooned on the stage [was] rich, or aristocratic, or powerful." ${ }^{1}$ Aristophanes had sailed close to the wind at the celebration of the Great Dionysia of 426 B.C. when he lampooned the demagogue Cleon in the Babylonians, and was prosecuted for his pains. ${ }^{2}$ Even power legally used could be frightening. The means by which the powerful might be successfully ridiculed is indicated by the plot summary of a play by Aristophanes' older rival Cratinus, which came to light on a papyrus fragment first published in 1904. Cratinus "satirized Pericles with great plausibility by means of emphasis, because he brought the war on the Athenians." 3 "Emphasis" was a technical term meaning "innuendo," or even "subliminal suggestion," rather than "explicitness" as it does today. ${ }^{4}$ It was defined by Quin-

I. [Xen.] Ath. pol. 2.18, written in c. 430 B.c.: on the date, see Ostwald 1986, I82 n. 23.

2. Acharnians 377-382, and Schol. 378; Acharnians 502-503, and Schol.; Ostwald 1986, 207. 3. POxy. 663, 44-48; CGFP, 70; Cratin. Dionysalexandros i, PCG.

4. "We [today] are simply not attuned to writing which proceeds by indirect suggestion rather than by direct statement. ... When we 'emphasize' something, we proclaim it to our readers, leaving no doubt that we want its presence known. The ancient writer does the exact opposite": Ahl 1984, 179; 1991, 22-24. 
tilian as "the process of digging out some lurking meaning from something said," 5 and Demetrius the rhetorician (writing in the fourth century B.c.) stated that "the effect of an argument is more formidable (deinoteros) because it is achieved by letting the fact make itself manifest (emphainontos) rather than having the speaker make the point for himself." 6 According to a tradition that may go back to Aristotle, the device was one of the distinguishing characteristics of Greek comedy, which "differs from abuse, since abuse delivers the insults in an unconcealed manner, whereas comedy needs what is called émphasis." " "Emphasis," moreover, contributes greatly to the allegorical pictures Aristophanes creates. Hidden meaning, innuendo, and double entendre are, however, not to everyone's taste today. It will be explained presently how this came about, and when the break with the pattern that had prevailed in antiquity occurred.

Very occasionally, Aristophanes will make explicit what was either implicit or self-evident (in view of the masks and costumes the actors wore). Near the beginning of Peace, two slaves are busy feeding the dung beetle on which Trygaeus will fly up to Olympus. One of them says: "Some bright spark in the audience may be saying "What is this about? What does the beetle mean?" The other replies that the person sitting next to him will declare, "It seems to me that he is hinting at Cleon, saying that he shamelessly eats dung" (Peace 43-48). The word for "hint" is ainittetai, cognate with ainigma ("enigma" or "riddle"). Cleon was a politician much hated by Aristophanes, but he had died a few months before Peace was performed in 42I B.C. The procedure to which Aristophanes here draws specific attention is not confined to this passage, but (or so it will be argued in this book) is widespread throughout Aristophanes, where it is usually put across "emphatically." For want of a better term, I have called it "political allegory."

The most powerful Athenian politician during much of Aristophanes' lifetime was not Cleon but Alcibiades, who had been Pericles' ward, and who began to lay claim to Pericles' political mantle during the 420 . He was elected general for $420 / 19$ в.C., and was to be re-elected for the next five years, before going into exile in $4 \mathrm{I} 5$ B.C. ${ }^{8}$ There are enough stories about Alcibiades' role in the theatre to justify the assumption that it would have been wise to make any attacks on him covert. He is said - and even if the stories were ben

5. Quint. Inst. 9.2.64 (trans. Ahl 1984, 176).

6. Demetr. Eloc. 288 (trans. Ahl I991, 22-25).

7. Tractatus Coislinianus 31-32 Koster. On the possible derivation of the Tractatus from Aristotle's lost Poetics, see Janko 1984. Cf. Per. I6.I: in describing the way in which comic writers lampooned Pericles, Plutarch calls their technique parémphasis.

8. Develin 1989, 142-150. 
trovate, they indicate the kind of man the ancients considered Alcibiades to have been - to have beaten up a rival choregus "before the audience and judges," ([Andoc.] 4.20-2I), ${ }^{9}$ to have prevented Aristophanes from winning first prize for Clouds in 423 B.c. by intimidating the judges (Clouds, Arg. 5 Coulon), and to have gone to the Record Office and "expunged with his wetted finger" an indictment against the comic poet Hegemon of Thasos (the officials were afraid to renew the charge "on account of Alcibiades") (Ath. 9.407c). Eupolis, another comic writer, clearly went too far in the Baptae when he drew Alcibiades' especial anger by "openly lampooning his traulotèta" (Tzetz. XIAi 89 Koster).

Trauloteta was a speech defect whereby rho is pronounced as lambda: such a confusion could deliver meanings in Greek as different from each other as "Kids fly free" and "Kids fry flea" in English. In Alcibiades' own mouth the disorder was not considered especially offensive by contemporaries, "but was thought to be full of charm, and to have added persuasiveness (pithanótēta) to his discourse" (Alc. I.6). The phenomenon is not uncommon, even today: "Many politicians and others dependent on public esteem go in for lisps, stutters and bizarre pronunciations . . . and these afflictions may serve to make the sufferer more likeable." ${ }^{10}$ It was presumably because it was to his social and political advantage to do so that Alcibiades' son later adopted both his father's distinctive gait and his mode of speech: klasaukheneuetai te kaì traulizetai ("he bends his neck in an affected way and pronounces rho as lambda"; Archipp. PCG 48 ap. Alc. I.8). Traulism, or lambdacism, was a speech mannerism peculiar - in the 420 S B.C. - to Alcibiades. ${ }^{11}$ Aristophanes draws specific attention to it in the Wasps, ${ }^{12}$ where a slave says that he saw in a dream a certain Theorus with the head of a kórax (crow). Then (44-45) Alcibiades is supposed to have said to him traulisas ("lambdacizing"): holâis; Théōlos tè̀n kephalèn kólakos ékhei ("Do you see Theolus? He has the head of a flatterer"). He should have said: horaiis; Théōros tè̀n kephalèn kórakos ékhei ("Do you see Theorus? He has the head of a crow"). There are special reasons why the lambdacism is spelled out here (and these will be discussed in Chapter 7). Normally, lambdacism would not have been indicated

9. For arguments in favor of the authenticity of this speech, see Raubitschek 1948; Furley 1989; cf. Alc. I6.5; Dem. 2I.I47.

Io. Sayle 1988, Iо.

II. Alcibiades the younger, Demosthenes (see Stanford 1967, I52 n. Io for refs.), and Aristotle (Diog. Laert. 5.I) also shared the same speech impediment (which is often translated "lisp" for want of a more accurate term). For a good discussion of the condition, see O'Neill 1980 (a reference I owe to the kindness of David Crystal).

12. Wasps 42-46; cf. Clouds 862-864 and I38I-1384 (discussed below in Chapters 3 and 7).

Nicias, Lamachus, and Alcibiades : xvii 
in the text, as Quintilian explains: lambdakismós, along with iotacism, a soft voice, and broad pronunciation (and Quintilian uses the Greek words for these expressions, though he wrote in Latin) "happen through sounds, and ... cannot be shown in writing because they are errors in speech and of the tongue." 13

The impediment was an obvious handle for mockery on the stage (and elsewhere), and playwrights (and others) exploited the possibilities for double meanings presented by Alcibiades' idiolect. We find Aristophanes doing so from Knights onward. His rival Eupolis clearly got Alcibiades' goat in Baptae. Not only does Alcibiades seem to have punished Eupolis (having some of his cronies "baptize" the poet in the sea), ${ }^{14}$ but he is said to have "passed a law to the effect that comedy should no longer be written openly, but figuratively" (Tzetz. XIAi 97-98 Koster). The authority for this statement is very late, but if, as seems likely, the Baptae was performed during the year or two preceding the Sicilian expedition, ${ }^{15}$ there may be support - albeit flimsy ${ }^{16}$ - in the legislation passed in 4I5 B.C. and associated with the name of Syracosius. This stated that it was henceforth illegal to lampoon people on stage by name (mì kōmōideîsthai onomastí tina; Schol. Birds I297).

There has been no end of scholarly debate over the meaning of Syracosius' legislation. ${ }^{17}$ Since some thirty-seven Athenians are mentioned in Birds, performed in the following year (4I4 B.C.), it has been suggested that the legislation was a dead letter, if it existed at all. The absence from Birds of the names of any of those found guilty of parodying the Eleusinian Mysteries or the mutilation of the Herms has been noted, and the law has been held to have applied to them: that they should not be mentioned on the stage. ${ }^{18}$ This may be to miss the point; the reality may have been that Aristophanes was simply obeying the law in not mentioning by name those who were being seriously lampooned - namely, the "rich, the aristocratic, and the powerful." Aristophanes is in any case said, albeit by the same late authority, to have

13. Quint. Inst. 1.5.32; Ahl 1991, 96. Quintilian's statement will account for the lack of any indication of lambdacism in some lines of Eupolis ( $P C G$ 385) that Meinecke (FCG 3:368) plausibly suggested were spoken by Alcibiades and another. It is not a question of the feature "not being sustained": Halliwell $1990,76$.

I4. Tzetz. XIAi 89 Koster: "Baptize me on stage and I will soak you in salt water"; an authentic couplet, according to West 1972, 29-30; 1974, 17.

I5. Storey 1990; 1993.

16. Halliwell (1991, 55-56) well shows how flimsy the evidence is.

17. Halliwell (1991, 54-66) has captured the essence of a discussion that at times verges upon the theological.

I8. Sommerstein 1986, IOI-I08, with references to earlier literature. 
been among those who practiced symbolic satire after 4 I5 B.c. (Tzetz. XIAi 99-I00 Koster). It will be argued below that many of the names of real people who are specifically mentioned are simply vehicles for the lampooning of the major targets. The latter, and not the individuals concerned, are properly the kōmoiidouménoi ("those who are satirized").

Alcibiades' apparent absence from comedy has been a matter for frequent comment. Thus: "Aristophanes makes surprisingly few references to the aristocratic Alcibiades," 19 "Alcibiades appears surprisingly infrequently in Aristophanes and the fragments of other dramatists," 20 and "Alcibiades, however surprisingly, does not appear to have been a particularly appealing butt for comic poets at any point in his career." ${ }^{21}$ Then, "references made by Athenian dramatists to Alcibiades in the years 4I4-4II B.C. are only to be found in a very limited quantity," 22 and in the specific context of Birds, it was noted long ago that Alcibiades is nowhere mentioned by name. ${ }^{23}$ Scholarly surprise was due to the fact that Alcibiades not only was "rich, aristocratic, and powerful," but also was the most controversial individual of his age, having been elected one of the three generals for the Sicilian expedition (a campaign he had done much to promote); having been suspected of involvement in various acts of impiety before the departure of the fleet; having been recalled from Sicily to stand trial; having jumped ship and gone into exile at Sparta; having advised the Spartans on the most effective ways to defeat Athens; and having, so rumor had it, seduced and gotten with child Timaea, the wife of the Spartan king.

\section{NWe \\ THE PROBLEM WITH POLITICAL ALLEGORY}

Birds in fact provides a useful testing ground for theories of allegory in Greek drama. There is nothing new in seeing the play as an allegory in which Alci-

19. de Ste. Croix 1972, 36 r.

20. Heath 1987a, 34. For a good account of the places where Alcibiades is mentioned specifically in Aristophanes, see Moorton 1988, 345-359. They are not many, however; cf. Hertzberg 1853, I5: "— auch bei Aristophanes wird Alkibiades verhältnissmässig selten erwähnt."

21. Halliwell I991, 6I.

22. Hertzberg I853, 303. Cf. Halliwell 1991,60 , on "comic poets' particular silence about the controversial figure of Alcibiades during [the] period [415-4II]."

23. By Droysen (1835, I6I-208). This can only in part have been due to the difficulty of fitting Alcibiádès into verse (noted by Critias 4 [West]); ho Kleiniou ("son of Cleinias") could be (and was) employed instead. 
biades underlies the hero Peisthetaerus, but "the majority of scholars today ... flatly reject a political reading"; ${ }^{24}$ Birds has "no strong and obvious connection with a topical question of public interest"; 25 "attempts to find in Birds any extensive allegorical comment ... are unconvincing." ${ }^{26}$ Allegorical readings had their advocates - in some quarters at least — during the eighteenth and nineteenth centuries. Perhaps the most influential work in this respect was J. W. Süvern's study of Birds of 1827, which appeared in an English translation in $1835,{ }^{27}$ but which is now generally dismissed as an analysis that "in its failure to persuade posterity, remains a warning against eagerness to credit the play with an explicit political design." 28 Süvern was reacting against the position adopted by A. W. von Schlegel earlier in the century: "that the Birds was nothing more than the fantastic exuberance of poetic genius, soaring with light wing into an airy region of its own creation, but yet with a shrewd eye for the follies of a world from which it pretends to have shaken itself free." ${ }^{29}$ This, however, is the position taken by most scholars today; Cedric Whitman went even further, maintaining that "the theme of the Birds is absurdity itself . . . it is about meaninglessness." 30 The nineteenth-century dichotomy between "allegory" on the one hand and "fantastic exuberance" on the other was neatly categorized by the Swiss scholar H. Köchly in political terms, as a division between Right and Left. ${ }^{31}$ This is in many ways a useful model, for it is possible to perceive a growing dislike for allegory as one of the elements in the secular clash between the old truth and the new, between faith and science, between conservatives and liberals.

Greek studies developed in northern Europe during the sixteenth and seventeenth centuries as a means of challenging the traditional authority of the Roman church. The Greek New Testament of Martin Luther was the weapon used to attack an institution whose spiritual claims appeared to rest on a Latin pun. ${ }^{32}$ The Renaissance tradition of cloaking secrets in the fabric of fables was

24. Konstan 1990, 187; he cites with evident approval Whitman 1964, 169: "Birds . . is strangely free of political concerns." For an exception to the general trend, see Arrowsmith 1973. 25. Sommerstein $1987, \mathrm{I}$.

26. Dunbar 1995, 3 .

27. Süvern 1827; 1835 .

28. Dobrov 1990, 214; cf. Arrowsmith 1970, 7.

29. Merry 1904, 18, characterizing Schlegel 1809 .

30. Whitman 1964, 179 .

31. "Wie bei einer parlamentarischen Versammlung, so treten auch hier zunächst in schärfstem Gegensatz eine Rechte und eine Linke sich gegenüber": Köchly 1857, I.

32. "Tu es Petrus et super hanc petram aedificabo ecclesiam meam," inscribed around the base of the dome of St. Peter's. On the connection between Protestantism and Greek studies, see Lloyd-Jones 1982, 19; cf. Bernal 1987, 193-194. 
a potent one, ${ }^{33}$ but its practitioners served a largely courtly public. The court ethos "cherished the display of wit and playful forms of expression that led to deeper truths." ${ }^{4}$ Classical scholarship had begun in this tradition, but was going in another direction. At the end of the seventeenth and in the early eighteenth century there was a "diminishing tolerance of error, an increasing demand for precision," 35 coupled with a growing skepticism with regard to the claims made in some quarters regarding the authenticity of certain ancient texts. The Whig scholar Richard Bentley presented powerful arguments against those who believed that the letters of Phalaris were by the sixthcentury B.C. tyrant of Sicilian Acragas. The essay in which Bentley methodically demolished his Tory opponents' case is a classic of its kind. ${ }^{36}$ The creation of the science of Altertumswissenschaft in early-nineteenth-century Germany and its attendant specialization led to what its proponents regarded as an increased rigor in the treatment of ancient literature. ${ }^{37}$ But a "science" that had begun as a defense of the Word of One God was perhaps illequipped to understand a culture that worshiped many gods.

A love of Greece was also a means by which liberals expressed their opposition to an ancien régime that reckoned its descent from exiled Trojans, ${ }^{38}$ and whose members derived moral and ethical truths from emblem books and amused themselves with riddles. Both emblem books and riddles were to lose their status under the new order. ${ }^{39}$ Puns went the same way. The Whig wit, the Reverend Sydney Smith (I77I-I845), had

very little to say about puns; they are in very bad repute, and so they ought to be. The wit of language is so miserably inferior to the wit of ideas, that it is very deservedly driven out of good company. Sometimes, indeed, a pun makes its appearance which seems for a moment

33. Wind 1966.

34. Kaufmann 1990, 72; cf. Winkler 1991, 35-37.

35. R. H. Griffith 1945 , 156.

36. Bentley 1699; I883.

37. Pfeiffer 1976; Wilamowitz-Moellendorff 1982; Bernal 1987.

38. "The Greek cause was supported in England by ... Whigs and Radicals": Blake 1982, 32. On the supposed Trojan descent of, e.g., the Habsburgs, see Laschitzer 1888 (esp. pl. I: "Hector Priami Magni Regis Troianorum Fil[ius]"); cf. MacDougall 1982.

39. See the Chronological Index in Heckscher, Sherman, and Ferguson 1984, 8I-90: emblem books published in the sixteenth century take up $2^{1 / 2}$ pages, in the seventeenth century 4 , in the eighteenth century $\mathrm{I} 1 / 2$, and in the nineteenth less than $\mathrm{I}$. On riddles, see Bryant $1990,5 \mathrm{I}$ : "With the coming of the nineteenth century there began a decline in the esteem in which the riddle was held." 
to redeem its species; but we must not be deceived by them; it is a radically bad race of wit. ${ }^{40}$

Classics, meanwhile, had become a subject whose principal pedagogical aim was to teach the young to express themselves unambiguously; ambiguity in ancient literature consequently tended to be overlooked. Since "hidden meanings" were in essence "kitsch," ${ }^{41}$ they came to be disregarded, even derided. ${ }^{42}$ Puns might be explained away as "accidental"; ${ }^{43}$ when this was clearly impossible - as with those of Aristophanes - they might be dismissed as "rarely sophisticated." 44 But then, "few scholars are so Oedipal as to seek what they consciously do not wish to find." ${ }^{45}$ If it is true that "tyrants and terrorists pun sparingly," 46 their opponents often find ambiguity to be an effective means of safe criticism. Allegory - and certainly political allegory — went out of scholarly fashion; it was only tolerated in the form of what De Quincey called "impersonated abstractions." 47

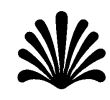

\section{AMBIGUITY IN GREECE}

By contrast, the ancient Greeks were very keen on ambiguity - in its placeand on disguising (or enhancing) fact with fiction. A prime example is to be found in the Protagoras, where Plato makes the Abderite philosopher ask his audience whether he should make his case mûthon légōn ("in the form of a myth") or go through it in a factual way (Pl. Prt. 320c). His listeners choose the myth. Isocrates, writing in the fourth century B.C., put matters very nicely when speaking of logoùs amphibólous ("ambiguous words"): "arguments the employment of which, when one contends in court over contracts for his own advantage, is shameful and no slight token of depravity but, when one

40. S. Smith I886, 24I-242.

4I. If Roy Pascal is correct that "the recommendation of obsolete values is the essence of kitsch": 1973, 38; cf. 294-295.

42. Dover 1958, 235.

43. Contrast, "The pun is not natural, it is an art form and thus not careless": Ahl 1988, 25; cf. Vendryes I921, 209; Redfern 1984, I5.

44. Dover 1968, 96.

45. Ahl I988, 2I-23.

46. Hall 1984 , 100.

47. De Quincey 1857, 28I; cf. Newiger 1957. The primary sense of "allegory" in $O E D^{2}$ (s.v.) is "description of a subject under the guise of some other subject of aptly suggestive resemblance." 
discourses on the nature of man and of things, is fine and philosophical." 48 Poetry was another area where ambiguity might exist. W. B. Stanford, writing in prewar Trinity College, Dublin, amid the last vestiges of the ancien régime, and in the city of those consummate wordplayers James Joyce and Myles na Gopaleen, was one of the few to recognize the fact:

No genre of Greek poetry is entirely free from deliberate ambiguities, whether trivial puns, superstitious or sophistical etymologies, cryptic oracles, diplomatic evasions, cunning and deceptive equivocations, humorous or cacemphatic doubles entendres, unconscious foreshadowings of catastrophe, allusive phrases, associative meanings and vaguenesses, or any other of the manifold devices of ambiguity in its widest sense. Simpler lyric poetry had least of it, drama most. ${ }^{49}$

These devices might be employed in the service of political allegory in both serious and comic contexts. A good example of the former is to be found in Bacchylides' Dithyramb for the Athenians (18 Snell), written in the late 470 B.C. apparently employing the career of Theseus as a graceful tribute to Cimon, his family, and his exploits. ${ }^{50}$ The conjunction of a kuneàn Lákainan ("Laconian cap") and an oúlion Thessalàn khlamúd' ("woolly [or 'deadly'] Thessalian cloak") must allude, albeit "emphatically," to Cimon's twin sons Lacedaemonius and Oulius, and to their brother Thessalus. John Barron has persuasively argued that references to "Lemnian fire" in Theseus' eyes and his "auburn" hair refer to Cimon's parents, Miltiades, the captor of Lemnos, and Hegesipyle, a Thracian princess. The message of these lines must be that Cimon "is a second Theseus": appropriate for one who brought Theseus' bones to Athens in the 470 Os B.C. ${ }^{51}$ Bacchylides' other Thesean dithyramb (I7 Snell) has been called "a manifesto for the Delian League," and describes a scene that was also depicted in a mural in Cimon's Theseum, namely the hero's visit to the underwater realm of his father Poseidon. Again certain words in the poem stand out, and can only be explained by reference to Cimon. Theseus visits his hippiou ("horsey") father: Cimon's family was the "horsiest" in Athens (his grandfather Cimon had won the Olympic chariot race in 536,532 , and 528 B.c. with the same team of mares; Hdt. 6,103.2-3).52 Amphitrite places a distinctive garment, an ä̈ona, around him. The word is exceptionally rare, and must play on Ë̈ö́n, Eion, the city on the

48. Isoc. 2I.240; cf. Stanford 1939, I3.

49. Stanford 1939, I8I-182.

50. Barron 1980; Francis 1990, 53-66.

5I. Barron 1980, 2.

52. Ibid., 3 . 
Strymon that was the site of the Delian League's first victory, won under Cimon. ${ }^{53}$ Elsewhere, a dead Trojan named Eioneus ("the man of Eion") was included by Polygnotus in the mural decoration of the Lesche of the Cnidians at Delphi (Paus. I0.27.I), and his presence, too, must reflect Cimon's first great triumph; by allusive means, an allegorical equation is thus made between Cimon's victory at Eion and the Sack of Troy. ${ }^{54}$ Myth could indeed be "readily adjusted or invented in the service of state, family or politics." 55

The same "emphatic" approach to historical events and the individual's role in them was employed by writers for the Athenian comic stage. Instead of graceful compliments, however, insults were the common coin. Wordplay, ambiguity, and "emphasis" lent themselves admirably to a "discourse on the nature" of particular individuals, and were especially useful when those who were "rich, aristocratic, and powerful" were in the line of fire. Much hinges on the level of sophistication of Aristophanes' audience. There are those who would see them as peasants, ${ }^{56}$ but this is perhaps an instance of the "impoverishment of the past," to which I have alluded elsewhere, ${ }^{57}$ and to which there are welcome signs of reaction..$^{58}$ Rather, Aristophanes was writing for an audience that included many who were urbane and politically aware, alert to any nuance, equivocation, or ambiguity; in short, "sophisticated." He was not writing for peasants and potters.

Much of what is imputed by these various means is at the level of gossip, and much may well never have actually occurred in real life. Some incidents or conceits in any case had their origins in the exaggerations of comic writers - frequently grounds for dismissing elements of the anecdotal tradition out of hand, but in the present context all to the good. But although the historicity of some of the events and imputations discussed here may be open to question, the historical significance of the fact that such things were said, joked about, or even believed should not be overlooked. As G. M. Young once observed: "The real, central theme of History is not what happened, but

53. Ibid., 4; Francis 1990, 62.

54. Barron 1980, 4; Francis 1990, 62, 95.

55. Boardman 1982, I. For excellent discussions of the topic, see Francis 1980; 1990.

56. E.g., Dover 1972, frontispiece, where the reader is invited to "contemplate the expression" on the face of a modern Greek peasant in order to "imagine the people who constituted the greater part of Aristophanes' audience."

57. Vickers 1987c; 1990b; 1990c; Vickers and Gill 1994.

58. Notably Goldhill 1987 , esp. pp. 58-59, where he criticizes the view that the "requirements of performance before a mass audience preclude, or at any rate severely limit, the possibilities of complex, problematic or obscure expression in the tragic texts"; the same considerations apply to comedy. 
what people felt about it when it was happening." ${ }^{59}$ And the role of gossip in a "shame-honor" culture such as that of ancient Athens should not be underestimated. If gossip did indeed "play with reputations," ${ }^{00}$ how much more effectively could this be achieved on the comic stage. If "talk dragged details of men's private lives into the public arena for inspection and condemnation," 61 writers of comedy will have capitalized on the fact. In a society that "lacked organized news media," 62 the comic theatre will have served as an effective means of dissecting rumor and gossip. It will be taken for granted in what follows that if there is a prefiguration in comedy of a story preserved in the anecdotal tradition, then the two are related. Whether the prefiguration or the story has a basis in fact will not be my concern. All I hope to demonstrate is that there is a sufficiently large overlap between tales told about members of Pericles' extended family and the plots and situations that occur in Aristophanes' extant plays to justify a belief in political allegory.

It was probably with good reason that Aristotle mentions Pericles' ward Alcibiades in his analysis of the difference between poetry and history:

The historian and the poet do not differ in that they use metrical or unmetrical language. ... The difference is that the one tells of events that have happened, the other of such as might happen ... poetry expresses the universal, history particulars. Now, "the universal" consists in describing the kind of things that a person of a certain character would say or do probably or necessarily. ... An example of the particular is what Alcibiades did, or what was done to him. (Arist. Poet. 9,2-4)

It is tempting to think that Aristotle is implicitly saying that the poet (he is speaking of the dramatic poet) shows the kind of thing that someone like Alcibiades might say or do, given his known propensities. ${ }^{63}$ This is what the Antiochene polymath Libanius seems to have implied centuries later when he posed the rhetorical question: "What play did not include [Alcibiades] among the cast of characters? Eupolis, Aristophanes, did they not show him on the

59. G. M. Young, cited in Marcus 1966, III. Cf. Strauss 1990, 122: "The truth of [the anecdotes about Alcibiades' youthful adventures] hardly matters; much more important is that Alcibiades elicited them."

60. Spacks 1985, 4; cf. Hunter 1990. Aspasia provides a prime example; see M. M. Henry 1995, 19-28.

6I. Hunter 1990, 322.

62. Ober $1989, \mathrm{I} 48$.

63. Cf. Else (1957, 313), who argues that the reason why Alcibiades is given as the example of a historical individual by Aristotle is "because he was a favorite and conspicuous butt of the Old Comedy." 
stage? It is to him that comedy owed its success" (Lib. fr. $50 \beta$ [5.644.5-7]). Given the information available to Libanius (the libraries of late-Roman Athens and Antioch will have contained rather more primary literature than is available to us), ${ }^{64}$ it is possible that he knew what he was talking about. It is also the case that Libanius has regularly been given short shrift by the learned, ever since his professors at Athens criticized him for skipping their lectures so that he could do his own research. ${ }^{65}$

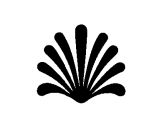

\section{ALLEGORY IN BIRDS}

It is a far from new idea that Birds is a parody of the situation in which Alcibiades found himself in $4 \mathrm{I} 4$ B.C. The idea was first put forward in modern times by Jacques le Paulmier de Grentemesnil. ${ }^{66}$ The Jesuit scholar Pierre Brumoy developed it at length in 1730 , and variants have been proposed by Süvern, Köchly, Blaydes, and others. ${ }^{67} \mathrm{~A}$ few years ago, I wrote an essay in similar vein, ${ }^{68}$ but not only did I ignore le Paulmier, Brumoy, and Süvern (whose works are discussed more fully in Chapter 9), but I also overlooked the full implications of another study, which I now find to be full of good sense. This was Barry R. Katz's demonstration that the three gods, Poseidon, Heracles, and the Thracian Triballus, who make representations to Peisthetaerus at Birds 1565-1691, are allegories of Nicias, Lamachus, and Alcibiades, the three generals who had been appointed to command the Athenian expeditionary force sent to Sicily in $4 \mathrm{IS}$ B.C. I was already convinced that Peisthetaerus himself embodied many recognizable characteristics of Alcibiades, ${ }^{69}$ and had not yet fully realized the extent to which Aristophanes might have reflected different facets of the same individual by means of different characters (who might even be on the stage at the same time).

Such "polymorphic characterization," as I have called it, might recently have seen an exploration of, say, the political career of Baroness Thatcher by means of the interaction of an Iron Lady, of St. Francis of Assisi, and of Queen Boadicea (embodying the belligerent, charitable, and patriotic per-

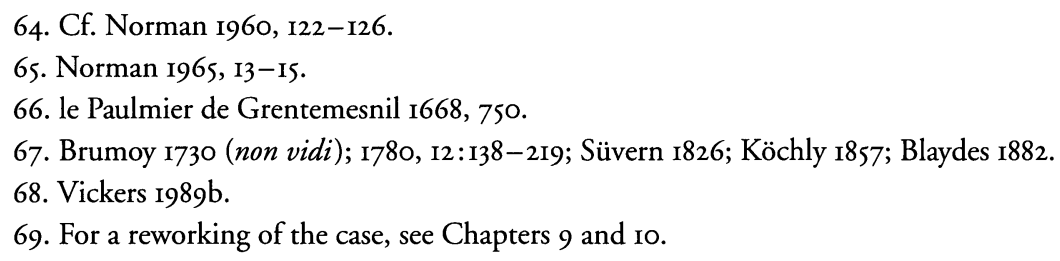


sonae of the former British prime minister). It was the perfect dramatic vehicle for representing a figure as multifaceted as Alcibiades, compared in antiquity to Proteus (Lib. Decl. I2.42 [5.558.16]) and a chameleon (Alc. 23.4), and supposedly descended from Daedalus (Pl. Alc. I.I2I). ${ }^{70} \mathrm{It}$ is a principle that can easily encompass both Peisthetaerus and the Triballian as reflections of Alcibiades. It is also — as we shall see - a principle that solves the problem of "discontinuity" that is supposed to afflict Aristophanes' plots.

Katz's argument is that "Aristophanes, amidst much comic foolery, intended his divine embassy of Poseidon, Heracles, and Triballos, who come to Cloudcuckooland to treat for peace, to remind his audience of the curious troika placed in charge of the Sicilian expedition" - of Nicias, Lamachus, and Alcibiades. ${ }^{71}$ And this is achieved very effectively. Poseidon's apparent leadership of the group reflects the unofficial seniority due to his age enjoyed by Nicias, and the way in which he is outvoted by his fellow envoys recalls how Nicias in Sicily had been outvoted by his fellow generals; his concern for propriety and decorum reflects a trait of Nicias, and his remark about the Triballian, "O Democracy, where will you lead us if the gods elect him" (1570-157I), reflects Nicias' opposition both to Alcibiades and to the Sicilian expedition. The unintelligibility of the Triballian's speech (which is very brief and mostly gibberish) is associated by Katz with Alcibiades' speech defect, and with his practice of hesitating in a speech and searching for the right word; his cloak may allude to Alcibiades' liking for long, trailing robes. Then Heracles' impatient desire immediately to strangle Peisthetaerus (I575) recalls Lamachus' proposal for a direct attack on Syracuse. Poseidon's reminder that the gods had been sent to make peace (I577) recalls Nicias' relatively pacific proposal on the same occasion, and the rough character of Heracles well corresponds to that of Lamachus, the tough "professional" soldier. The possibility that Heracles will be poor (1644) perhaps alludes to Lamachus' well-known poverty: he was so badly off that whenever he was elected general he would ask "the Athenians to advance him some money to provide him with clothes and shoes" (Plut. Nic. I5.I). Heracles' apparent eagerness to get a good meal may have something to do with Aristophanes' lampoon elsewhere of Lamachus' debts, his gluttony, and his dependence on state pay.

Such, in outline, is Katz's case. He also suggests that a reason for the Triballian's reticence, his presence on stage as a virtual "silent partner," might be to highlight the absence of Alcibiades from Athens. ${ }^{72}$ But if the tradition that

70. Hertzberg (1853, I4) speaks of Alcibiades' "geistige Elasticität."

71. Katz 1976, 353.

72. Ibid., 358.

Nicias, Lamachus, and Alcibiades : xxvii 
Peisthetaerus reflects the personality of Alcibiades is a valid one (on which see Chapter 9), the latter individual will already have been effectively present on stage. Aristophanes shows Peisthetaerus dressed as a swallow (I4I2), a bird whose twittering was regularly described in the same words (traulizein and traulós) as Alcibiades' speech defect. Peisthetaerus is characterized as a despot, the tyrant of Cloudcuckooland, recalling the fears expressed on the eve of the departure of the fleet for Sicily that Alcibiades was aiming at tyranny in Athens (Thuc. 6.15). The case has also been made (and will be made more fully below) that Birds lampoons an Alcibiades at Sparta who has bamboozled his hosts and dishonored Timaea, the Spartan queen. ${ }^{73}$ For present purposes, this is of secondary importance; one of the objects of this Introduction is to reinforce Katz's arguments so as to make it appear on balance likely that Aristophanes did employ political allegory.

Aristophanes uses both parallel situations and characteristic language to show the three gods as Nicias, Lamachus, and Alcibiades. Nicias was currently the admiral of the Athenian fleet in Sicily. If Aristophanes' idea of a marine god (theós) played on this, it was a witty conceit. Nicias was also notoriously superstitious. He kept a soothsayer in his house, was much given to divination (theiasmôi; Thuc. 7.50.4; cf. 7.77.2), and "never disregarded religious observances and omens" (Plut. Crass. 38.2). Poseidon's objection ( 1567 ) to the Triballian's wearing his cloak ep' aristerr' ("on the left" or on the side that "bode ill," was "sinister" or "ominous") 74 may allude to Nicias' habitual superstition. Similar considerations perhaps govern Poseidon's injunction (I568) to the Triballian to shift his cloak epi dexian ("to the fortunate side"). ${ }^{75}$ Poseidon's concern with neatness (cf. I573) recalls furthermore how Nicias had tidied up the Delian festival, making what had been a disorderly affair a stately procession (Plut. Nic. 3.5). The Triballian's himátion perhaps echoes the Alcibiadean reality even more than Katz thought, for not only did Alcibiades wear a "purple robe which he trailed through the Agora" (Alc. I6.I), but no fewer than twenty-two of his himátia had been put up for sale by public auction a few months before the performance of Birds. The details were recorded on an inscription visible to all. ${ }^{76}$

"How like Laespodias you are!" Poseidon complains of the Triballian at Birds 1569 . Laespodias was to be Nicias' fellow general for the year $4 \mathrm{I} 4 / \mathrm{I} 3$ B.C.,

73. Brumoy 1780, I2:184; Vickers 1989b; see Chapters 9 and Io.

74. LSJ s.v. aristerós.

75. Cf. LSJ s.v. dexiós II: "fortunate, esp. of the flight of birds and other omens." The gods' ambassadorial status (presbeúomen, I566) perhaps recalls Nicias' service as one of the envoys (présbeis) he had persuaded the Athenians to send to Sparta in 420: Thuc. 5.46.2.

76. Pritchett 1956, 167, 190-210; 1961, 23; cf. Lewis 1966. 
although his campaigning was in Laconia rather than Sicily (Thuc. 6.IO5.2). His infirmity (Laespodias is supposed to have had a gammy leg; Schol. Birds 1569), and the Triballian's supposed resemblance, may be an exaggerated allusion to Alcibiades' gait, which (together with his diction) was later to be imitated by Alcibiades Junior. It was said of the latter that "he walks (badizei) in an affected way, dragging his himátion behind him, so as to resemble his father" (Archipp. PCG 48 ap. Alc. I.8).

Aristophanes' allegory may be rather more sophisticated than this, and perhaps operated on more than one level. In keeping with the subtext of the play, the ambassador gods are characterized as Spartan deities. Heracles was believed to have been the ancestor of a line of Spartan kings, ${ }^{77}$ Poseidon had important sanctuaries at Cape Taenarus and at Sparta itself, ${ }^{78}$ and the Thracian Triballians were probably allies of the Spartans. ${ }^{79}$ There may also be a pun on the name Trib-allian and the tribon-a simple cloak, but characteristic of Sparta. (The Spartan way of life was characterized as "barley bread and a tríbona [Spartan cloak]"). ${ }^{80}$ Alcibiades in exile had for the moment thrown in his lot with the Spartans, and it might have been diverting to see the men who had been his co-generals in 415 B.C. doing the same, but in the safe, fictional world of the stage. Again, this is secondary to the principal purpose of this Introduction, except that it serves to explain why Heracles expresses the wish (1575) to "strangle" Peisthetaerus: "strangling" was the regular form of capital punishment at Sparta (cf. Plut. Agis 19.6, 20.I, 20.5), and Alcibiades had recently been condemned to death in absentia by the Athenians. The reason Heracles wants to kill Peisthetaerus is because he is blockading (apoteikhisas) the gods (I576). It may be more than a coincidence that Lamachus was building an apoteikhisma ("fortification wall") on Euryalus above Syracuse at the time Birds was performed (Thuc. 6.99.I), whereas Alcibiades conspicuously was not.

Poseidon reminds his companions that they are ambassadors for peace (1577). This might not be just a reflection of Nicias' relatively peaceable approach to his Sicilian adversaries, ${ }^{81}$ but also an allusion to Nicias' activities as a peacemaker in the 420 B.C., which culminated in the Peace of Nicias, of

77. Hdt. 8.131; Paus. 3.1.5; Ath. 12.535b; Alc. 23.8.

78. Paus. 3.25.4; cf. 3.12.5, 3.14.2. Poseidon's shrine at Taenarus included the cave wherein Heracles was said to have taken Cerberus prisoner: Guarducci 1984, IOI.

79. Thucydides speaks of the Triballoi defeating Sitalces, the Athenians' Thracian ally, in 424 (4.IOI.5).

8o. Plut. Cleom. 16.7; cf. lakōnizein kaì tríbōnas ékhein ("to behave like a Spartan and wear a simple cloak"), [Dem.] 54.34.

8I. Cf. Katz 1976, 36r.

Nicias, Lamachus, and Alcibiades : xxix 
which Lamachus was a cosignatory. ${ }^{82}$ Heracles' interest in the meat Peisthetaerus is cooking does, as Katz suggested, recall Aristophanes' lampoon of Lamachus in Acharnians (of 425 B.C.), but there is more that might be said. Lamachus' being deprived of a feast because he had to go on maneuvers at Acharnians 1085-II42 was presumably a jibe at his dependence on state support, and the information imparted by a servant at Birds 1589 that "there is no oil in the flask" may also find an explanation in Acharnians, where the lampooned Lamachus polishes his shield with oil (Acharnians II28). Lamachus could, moreover, be mentioned by name in 425 B.C. because it was not yet against the law to do so - or because he was neither rich, nor aristocratic, nor powerful.

Poseidon (probably; the Ravenna and Marcian manuscripts are unclear as to who delivers the speech at 1591-1595) tells Peisthetaerus that the divine envoys have not come to make war for personal gain (ou kerdainomen); one of the accusations that Nicias made against Alcibiades when the Sicilian expedition was debated was that he was in it to serve his own ends (idión héneka kerdôn; Plut. Nic. 12.4; cf. Thuc. 6.15.2). "Pools of water in the marshes, and halcyon (alcuonidas) days" will be granted in exchange for peace. There may be a pun here on Alcibiades' name, as well as a reference to his current place of refuge, for Sparta was exceedingly swampy (cf. Strabo 8.5.I), and there was even a marsh next to one of the kings' houses (Xen. Lac. 15.6), where Alcibiades was currently outstaying his welcome. The claim that Poseidon and Heracles have come as plenipotentiaries (autokrátores) may allude not only to the current status of Nicias and Lamachus as generals possessing full powers (autokrátoras; Thuc. 6.8.2; cf. Plut. Nic. 12.6), but also to an occasion in 420 B.c. when Alcibiades had caused Nicias great embarrassment by persuading Spartan ambassadors plenipotentiary (autokrátores; Thuc. 5.45.I; cf. 46.I), who had come to discuss outstanding differences after the Peace of Nicias, publicly to deny their true position. The result was a complete breakdown of the peace with Sparta, and its replacement - at Alcibiades' prompting with a peace with Argos (Thuc. 5.45-46). Alcibiades' fooling of the Spartan envoys had been achieved by means of "deceit and oaths" (Plut. Nic. Io.4; cf. Thuc. 5.45.2), and there may be something of this in Peisthetaerus' mention of "mortals who swear false oaths" (I609) and of perjury (I6II). Then, oaths sworn "by the Raven" (I6II) may be an "emphatic" allusion to a bad portent that had been observed at Delphi (the Raven was Apollo's bird) just before the departure of the fleet for Sicily. Ravens had pecked the golden fruit from

82. Thuc. 5.16.I, 19.2, 24.I, 43.2; Plut. Nic. 9.9; Alc. I4.2. 
a sacred palm tree (Plut. Nic. 13.5; Mor. 397f.). ${ }^{83}$ That ravens might peck the perjurer's eye out (1613) brings the response from Poseidon, "By Poseidon you speak sense in that at least."

Heracles goes along with whatever Peisthetaerus says (1603, I6I4; cf. 1626$27,1675,1685$ ), perhaps reflecting the relationship between Lamachus and Alcibiades; at the council of war at Rhegium at which Lamachus had spoken in favor of a quick attack on Syracuse, he "nevertheless gave his own voice for the proposal of Alcibiades" (Thuc. 5.50.I). It is Heracles who is open to Peisthetaerus' persuasiveness, and who is won over by his arguments, ludicrous as they are. The fantasy always has a basis in reality. Thus Poseidon and Peisthetaerus argue that if Zeus should die, Heracles will be a pauper on the grounds that as a bastard he cannot inherit (164I-1650). "Me, a bastard? What are you saying?" asks Heracles with some bewilderment (165I). If the historical Lamachus was in question, everyone in the audience will have been puzzled as well, for Lamachus was certainly legitimate. ${ }^{84}$ Peisthetaerus explains: "Because you are the son of a foreign (xéness) woman" (1652) — grounds for illegitimacy, and hence loss of citizen's rights. Lamachus' father was in fact called Xenophanes (Thuc. 6.8.2), which may explain the conceit.

The scene is full of puns, many of them the result of a confusion of lambda and $r h o$ in the mouth of Peisthetaerus. This kind of wordplay quickly palls today ${ }^{85}$ so I shall limit this particular discussion to two examples. First, at 1657-1658, Peisthetaerus refers to Poseidon being the first (prôtos) to claim Heracles' father's money (khrēmátōn). Hoûtos ho Poseidôn plōtós (for prôtos), however, would mean "Poseidon here afloat" - appropriate enough, given Poseidon's watery sphere. Second, Heracles' father's money (khrēmátōn), when lambdacized, produces a play upon klēmátōn ("shoes"). ${ }^{86}$ This might well be

83. Nicias had himself dedicated a bronze palm tree on Delos: Plut. Nic. 3.7.

84. Kirchner 190I-1903, no. 898r. For an interesting footnote to the bastardy of Heracles, see Callaghan 1990.

85. Cf. two modern examples: "Eleanor Roosevelt, discussing democracy with an oriental ambassador, asked: 'And when did you last have an election?' The diplomat, with some embarrassment, answered, 'Before blekfast'”: Redfern 1984, I64. Or the "Japanese" joke attributed to Woody Allen: "What is the difference between pussy and sushi?" "Rice."

86. Hsch.; see LSJ s.v. klêma III (and cf. kleímata and klima VI). If klêma does indeed mean "shoe," the judgment of Biel (1779-1780, 2:205; followed by M. Schmidt 1860, 493; and Latte 1966, 489) that Hesychius (who glosses kleimata, klêma, and klímata as hupodéma/ta ["shoe/s"]) misunderstood Jeremiah 48:32 (klimata soû diêlthe thálassan ["your branches passed over the sea"]) requires reassessment. Since the context there concerns "the vine of Sibmah," it is difficult to see how a confusion with shoes could ever have arisen. Best to take Hesychius at face value, with LSJ s.vv. The same "shoe" joke is repeated at I666; by $4 \mathrm{I} 4$ B.C. it will have been 
a witty allusion to Lamachus' poverty, which was so extreme that he had to ask the state for shoe money whenever he was elected general (Plut. Nic. I5.I).

Barbarous language was likened by the Greeks to the twittering of swallows. ${ }^{87}$ Traulizein, the Greek word for Alcibiades' speech impediment, was also used for "the twittering of swallows," and this is probably the linguistic association Aristophanes makes between Alcibiades and the Triballian (who has already been called barbarôtaton ["extremely barbarous"] at 1573) when the latter speaks gibberish, as much as alluding to Alcibiades' occasional hesitancy of speech..$^{88}$ The discussion between Heracles and Poseidon as to what the Triballian might have said in the lines (1678-1679) that Benjamin Bickley Rogers translated as "Me gulna charmi grati Sovranau Birdito stori," 89 and William Arrowsmith as "Gleep? Schnoozer skirt wotta twatch snock! Birdnicks pockle. Ugh," 90 has Heracles making an interpretation favorable to Peisthetaerus, but Poseidon objecting that he said the opposite, and continuing (168I), "unless he said to badizein ('walk') like the swallows." If, as was suggested above, the debate of the gods is based on the council of war held by Nicias, Lamachus, and Alcibiades at Rhegium, this line (which nearly every editor from Bentley onward has tried to emend) ${ }^{91}$ can stand, and be seen as a witty allusion (I) to Alcibiades' proposal to badizein against the Syracusans (after having won over the Syracusans' allies, beginning with the Messenians; Plut. Nic. 14.3), (2) to his "migration" (or desertion) from the Athenians, and perhaps (3) to Alcibiades' "funny walk," to which Aristophanes apparently drew attention at the beginning of the scene under discussion.

"Swallows" are mentioned again in the following line (1682), and Heracles soon falls in once more (1685-1687) with Peisthetaerus' demand for Basileia ("Sovereignty"). That Poseidon admits that he is outvoted (and cf. I630) could well reflect the outcome of the Rhegian meeting, for the policy adopted on that occasion was that of Alcibiades. Lamachus threw his lot in with Alcibiades, who then sailed off to try to persuade the Messenians to join the Athenians (Thuc. 6.50.I). ${ }^{92}$ Not long after this, Alcibiades was recalled to

\footnotetext{
a hoary one (see Chapters 2 and 3). For an attested pun involving a play on kappa and chi, see Pherecyd. ap. Diog. Laert. I.I19, where Krónos is turned into Khrónos (cited by Tate 1927, 215 n. 2).

87. E.g., Aesch. Ag. 1050; Schol. Birds 1680: barbarizein khelidonizein.

88. Cf. Katz 1976, 357.

89. Rogers 1906, 223.

90. Arrowsmith 1970, 130 .

9I. Blaydes I882, I67-168, thus lists half a score of such changes to the manuscript reading. Cf. Dunbar 1995, I24, 736-737.

92. But ouk épeithen ("he did not persuade [them]").
} 
Athens to face charges that were clearly derived from the Athenian public's fear that he was aiming at tyranny; but he escaped from his escort and duly "migrated." The way, however, that Poseidon appears to say, in effect, "I wash my hands of the whole business" (1683-1684), should relate as much to the way Nicias had declined sole command of the Sicilian expedition (Thuc. 6.23.3 $)^{93}$ as to his resignation to the will of his colleagues at Rhegium. Not only is Katz's case fully vindicated, but it is clear that Aristophanes' political allegory closely reflects the nuances of the politics of the year before Birds was performed.

If the evidence presented here is cogent, then political allegory may be present to a degree hitherto unsuspected. Line by line, word by word, nuance by nuance, Aristophanes creates complex and diverting images based on the recent adventures of Athens' most prominent son. He holds Alcibiades up to ridicule by means of "emphasis" and the witty use of allusive language, while also poking gentle fun at the foibles of Nicias and Lamachus. He seems to distance himself, for whatever reason (personal safety, obeying the law with regard to satirizing by name) by employing allegory. Or rather, he does not distance himself, but engages in an analysis of what happened that is richer and more evocative (and safer) - thanks to ambiguity at whatever level than any explicit account of the council of war at Rhegium might have been. Nor can it reasonably be claimed that "the passage do[es] not inevitably call Alcibiades to mind, and need not do so to be dramatically effective." 94 Rhegium will have been one of the last pieces of hard news - as opposed to rumor and gossip - that the Athenians had received about Alcibiades. It should also be clear that the number of puns, double meanings, and potential political references in the scene at Birds $1565-1693$ is too large to attribute merely to coincidence. (Or to put matters another way: if the parallels noted by Katz and the present writer were not contrived, then Aristophanes was being particularly insensitive.)

The reason for this preliminary excursus is to suggest that if political allegory can be shown to exist in the play of all plays that is supposed to lack any "explicit political design," 95 or that has "no strong or obvious connection with a topical question of public interest," 96 then it is not altogether unrea-

93. Cf. the occasion in 425 when Nicias publicly relinquished the command against the Spartans in Sphacteria in favor of Cleon (Thuc. 4.28, an act that Plutarch thought foolish centuries later (Plut. Crass. 36.I).

94. Moorton 1988 , 348, epitomizing Westlake $1980,42,47$, and 49 n. 32, on a different, but related, topic.

95. Dobrov 1990, 214.

96. Sommerstein 1987 , $\mathrm{I}$.

Nicias, Lamachus, and Alcibiades : xxxiii 
sonable to look for a similarly "emphatic" or allegorical commentary on recent history in earlier plays; nor is it unreasonable to find echoes of Aristophanes in Thucydides, who will have known how to read such allegory. We cannot hope to catch every allusion, but we are fortunate in that we possess something of the rich anecdotal tradition relating to the principal personalities whose policies, idiosyncrasies, and scandalous activities are lampooned by Aristophanes, namely Alcibiades, his guardian Pericles, and Cleon. Pericles was of course dead by the time Aristophanes wrote, but so, too, was Cleon when lampooned in Peace. The use - the indiscriminate use, some might say - of the anecdotal tradition raises questions of method that will be discussed in Chapter I. 


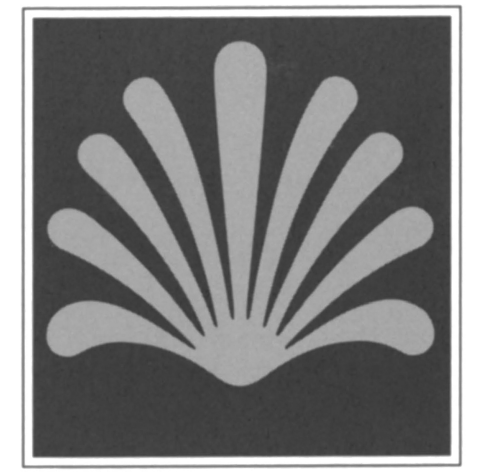

PERICLES ON STAGE 
THIS PAGE INTENTIONALLY LEFT BLANK 